\title{
ISTANBUL UNIVERSITY ISTANBUL MEDICAL FACULTY DEFICIENCY AND SOLUTION PROPOSALS DETECTED IN FORENSIC PATIENTS ADMITTED TO A TRAUMAAND EMERGENCY SURGERY OUTPATIENT CLINIC ISTANBUL ÜNIVERSITESI ISTANBUL TIP FAKÜLTESI TRAVMA VE ACIL CERRAHI POLIKLINIIĞi'NE BAŞVURAN ADLI OLGULARDA DÜZENLENEN RAPORLARDA SAPTANAN EKSIKKLİKLER VE ÇÖZÜM ÖNERILERi
}

\author{
Cüneyt Destan CENGER ${ }^{1}$, Ali Fuat Kaan GÖK², Beslen GÖKSOY ${ }^{3}$, Mehmet ILHAN $^{2}$, Birgül TÜZÜN ${ }^{1}$, \\ Nadir ARICAN ${ }^{1}$, Şebnem KORUR FINCANCI ${ }^{1}$, Cemalettin ERTEKIN ${ }^{2}$ \\ ${ }^{1}$ Departmant of Forensic Medicine, İstanbul University İstanbul Faculty of Medicine, Istanbul-Turkey \\ ${ }^{2}$ Department of General Surgery, İstanbul University İstanbul Faculty of Medicine, İstanbul- Turkey \\ ${ }^{3}$ Department of General Surgery, Şehit Prof. Dr. İlhan Varank Sancaktepe Training and Research Hospital, \\ Istanbul-Turkey
}

Öz

\section{Amaç}

İstanbul Üniversitesi İstanbul Tıp Fakültesi Hastanesi'nde 24 saat hizmet veren Travma ve Acil Cerrahi Polikliniği'nde düzenlenen adli raporların genelge, rehber, tıbbi yaklaşım ve tıp etiği çerçevesinde değerlendirilmesi ve bu kapsamda adli rapor standardizasyonunun tartışılması amaçlanmıştır.

\section{Gereç ve Yöntem}

01.07.2014-30.06.2017 tarihleri arasında çalışmacılar tarafından İstanbul Üniversitesi, İstanbul Tıp Fakültesi Travma ve Acil Cerrahi Polikliniği'nde başvuran erişkin ve çocuk olgulara ait adli olgular ve adli raporların değerlendirilmesi yapıldı.

\section{Bulgular}

İstanbul Üniversitesi, İstanbul Tıp Fakültesi Travma ve Acil Cerrahi Polikliniği'ne 01.07.2014-30.06.2017 tarihleri arasında başvuran 21500 hastanın 4964 adli raporu değerlendirildi. Adli raporlarda ilk sırada \% 39.5 oranında trafik kazası, ikinci sırada \% 31.2 oranla künt travmatik etkili eylem ve üçüncü sırada ise \% 9 oranla kesici delici alet yaralanması olduğu görülmüştür. Başvuruya yönelik değerlendirmede ise; \% 96.6'sında başvuru tarihi, \% 95.2'sinde başvuru saatinin belirtilmekte fakat sadece \% 5.5'unda başvuru şekli belirtilmişti. Çalışmaya dahil edilen adli raporların \% 88.3'ünde olay tarihi, \% 81.3'ünde olay saati belirtilmekle birlikte sadece \%12.9'unda olay öyküsünün kayıtlı olduğu saptandı.

\section{Sonuç}

Adli raporun hukuki standartlara göre olması adalet sisteminin hızlı ve doğru bir şekilde işlemesine neden olmaktadır. Hekimlerin, bu alanda hizmet içi eğitim programlarına "Adli olgu, Adli Rapor Düzenlenmesi" konusunun yanı sıra temel kanun ve yönetmeliklerde yapılan değişikliklerin eklenmesi, bu eğitimlerin periyodik olarak yapılması ile Üniversitemiz Travma ve Acil Cerrahi Polikliniği'nde düzenlenen adli raporlar-

İletişim kurulacak yazar/Corresponding author: dr.cenger@gmail.com

Müracaat tarihi/Application Date: 27.07.2019 • Kabul tarihi/Accepted Date: 08.10.2019

Available online at http://dergipark.gov.tr/sdutfd

Makaleye http://dergipark.gov.tr/sdutfd web sayfasından ulaşılabilir. 
daki hataları azaltacağı ve standartlara daha uygun adli raporların düzenlenmesinin sağlanabileceği kanaatindeyiz.

Anahtar Kelimeler: Adli rapor; adli tıp; hekim sorumluluğu; eğitim

\section{Abstract}

\section{Objective}

The aim of this study was to evaluate the forensic reports prepared in the 24-hour Trauma and Emergency Surgery Policlinic at Istanbul University Istanbul Medical Faculty Hospital within the framework of circulars, guidelines, medical approaches and medical ethics and to discuss the standardization of forensic reports in this context.

\section{Material and Methods}

Forensic cases and forensic reports of adult and pediatric patients admitted to Istanbul University, Istanbul Medical Faculty Trauma and Emergency Surgery Clinic between 01.07.2014-30.06.2017 were evaluated.

\section{Results}

4964 forensic reports of 21500 patients admitted to Istanbul University, Istanbul Medical Faculty Trauma and Emergency Surgery Outpatient Clinic between 01.07.2014-30.06.2017 were evaluated. In the forensic reports, 39.5\% traffic accident was the first, blunt traumatic action with $31.2 \%$ and stab wounds were the third with $9 \%$. In the evaluation for the application; $96.6 \%$ stated the application date and $95.2 \%$ stated the application time, but only $5.5 \%$ stated the application. Although $88.3 \%$ of the forensic reports included in the study stated the date of the event and $81.3 \%$ of the time, only $12.9 \%$ of the cases had a history of the event.

\section{Conclusion}

The fact that the forensic report is in compliance with legal standards causes the justice system to function quickly and accurately. We believe that by adding the amendments made to the basic laws and regulations to the training programs of physicians in this field, and by conducting these trainings periodically, the forensic reports prepared in the Trauma and Emergency Surgery Policlinic of our University will reduce the errors and that the forensic reports can be arranged in accordance with the standards.

Keywords: Medicolegal report; forensic medicine; physician responsibility; education

of specialists wanted to participate in postgraduate training programs due to their insufficient knowledge of forensic medicine (2). All sorts of allegations of assault and battery, abuse, negligence, accident and injuries either allegedly inflicted by one self or other person/s and/or animals are considered as forensic cases by physicians $(1,5)$.

The circular on "Forensic Medicine and Preparation of Medicolegal Reports" no. 13292 dated 22.09.2005 issued by the Ministry of Health General Directorate of Basic Health Services is used in the evaluation of forensic cases (6).

Article 2.2.b of the circular states the following: "Forensic medicine services in cities and town centers, where units affiliated with the Council of Forensic Medicine and universities that have an in-house forensic medicine department, shall be executed entirely by these institutions or in collaboration with healthcare organizations affiliated with the Ministry and entirely by health organizations affiliated with the Ministry when these institutions are not present." (6).

Article 3.3 of the circular states the following: "Medicolegal report forms should be filled completely; incident history, personal background, physical exam- 
ination findings, and examination and consultation date and time, if any, should be specified clearly. The medicolegal report should include, in detail, clinical findings, injuries, if any, and diagnostic test results, if performed. If the decision of a "life-threatening condition" is made in the forensic evaluation, findings that constitute the grounds for making the decision should definitely be specified in the conclusion section of the report. It should be taken into account if the examined person has consumed alcohol; this should be assessed duly if deemed necessary by the physician or requested by the judicial authority or the police, and the assessment should be included in the report. In light of ascertained findings, a definitive report should be prepared, if possible. However, in case the present examination and laboratory findings are not enough to prepare a definitive report about the person, then, a detailed preliminary-preliminary report/health status report should be elaborated, and the patient should be referred to a specialized healthcare organization for undergoing further examination and for preparing a definitive report." (6).

Upon publication of this circular, guidelines for the evaluation of injuries defined in the Turkish Criminal Code with regard to medicolegal reports were prepared by the Ministry of Justice, Directorate of Forensic Medicine Institute, Forensic Medicine Specialists Association, and Forensic Medicine Association in 2005 and were updated in 2013 (7).

This study aimed to evaluate forensic cases and medicolegal reports elaborated by the Trauma and Emergency Surgery Outpatient Clinic that works 24/7 at Istanbul University Istanbul Faculty Hospital within the frame of the circular, guidelines, medical approach and medical ethics and to discuss the standardization of medicolegal reports within this scope.

\section{Material and Methods}

In this descriptive and retrospective study, forensic cases and medicolegal reports of adults and children who were admitted to the Istanbul Medical Faculty Trauma and Emergency Surgery Outpatient Clinic at Istanbul University between 07.01.2014 and 06.30.2017 were evaluated by researchers. On 09.22.2005, circular no. 13292 regulating the Principles of Conduct in Forensic Medicine Services was published by the Ministry of Health General Directorate of Basic Health Services; after the publication of this circular, considering the circular and the guidelines prepared for the evaluation of criminal injuries defined in the Turkish Criminal Code in terms of forensic medicine and preparation of medicolegal reports issued by the Directorate of
Forensic Medicine Institute, Forensic Medicine Specialists Association, and Forensic Medicine Association in 2005 and updated in 2013, the following were retrospectively investigated in terms of their presence in medicolegal reports: report date; report number; date and time of admission to the health unit; type of admission to the hospital; name, surname, father's name, date of birth or age, gender, and medical identity of the patient; whether the patient or his/her relative submitted informed consent forms; type, date, and time of the incident; complaint and history of the patient; history of the family; habits, general condition, state of consciousness, cooperation, vital signs, and laboratory and radiological test results of the patient; referrals to other departments and results; medical examination findings; alcohol level; characteristics of external traumatic lesions if any (size, color, margin characteristics, depth, localization); whether traumatic lesions are marked on the diagram; presence of a life-threatening condition; whether simple medical intervention would suffice; interpretation of findings with comments/results regarding the type of trauma; characteristics of the report; seal or name and signature of the physician issuing the report; information regarding the employee receiving the report; seal and relevant information of the institution issuing the report; and patient data.

Report results and patient characteristics were compared using statistical methods. Data were recorded and statistically analyzed using SPSS for windows ver. 23. Data are presented as median, minimum, maximum, standard deviation, and mean. Distribution of variables was analyzed by the Shapiro-Wilk test. The Mann-Whitney test was used to compare two groups. The Kruskal-Wallis test was used to compare more than two groups. Results were within 95\% confidence interval, and the level of significance was set at $\mathrm{p}<0.05$.

\section{Results}

It was determined that 21,500 patients were admitted to Istanbul Medical Faculty Trauma and Emergency Surgery Outpatient Clinic at Istanbul University and $5,399(25.1 \%)$ medicolegal reports were issued between 07.01.2014 and 06.30.2017. Totally, 4,989 of these reports were retrieved from the hospital archives and included in the evaluation. Twenty-five $(0.5 \%)$ of these reports were not included in the study due to illegibility. The evaluation included 4,964 medicolegal reports.

The distribution of medicolegal reports according to incident type is presented in Table 1, wherein traffic 
accidents are leading incidents (39.5\%), followed by blunt trauma (31.2\%), and penetrating stab wounds (9\%). physical injury was observed in $77.2 \%$ (n: 3834) of the reports. Localization of injuries is presented in Graph 1. Head-neck lesions were most common with a number of 2,617 patients, while lower extremity lesions in 1,056, upper extremity lesions in 796, thoracic lesions in 393, back/lower back lesions in 237, and traumatic abdominal lesions in 139 patients, whereas some patients had traumatic lesions in more than one body region.

Admittance circumstances were not recorded in most of the reports while 474 patients were admitted to the hospital by calling the emergency line 112, and one patient was brought to the hospital by the police.

Findings regarding the identification in medicolegal reports that were included in the study are presented in Graph 2. From the aspect of admission, 4,795 (96.6\%) reports contained the date of admission, $4,725(95.2 \%)$ of them covered the time of admission, although only 275 (5.5\%) included the type of admission.

\section{Graph 1}

Localization of Traumatic Lesions (N:3828)

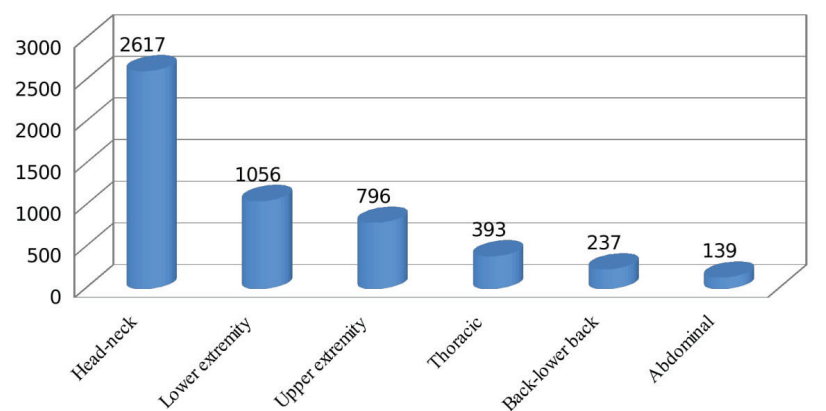

Graph 3

Evaluation of findings obtained during examination

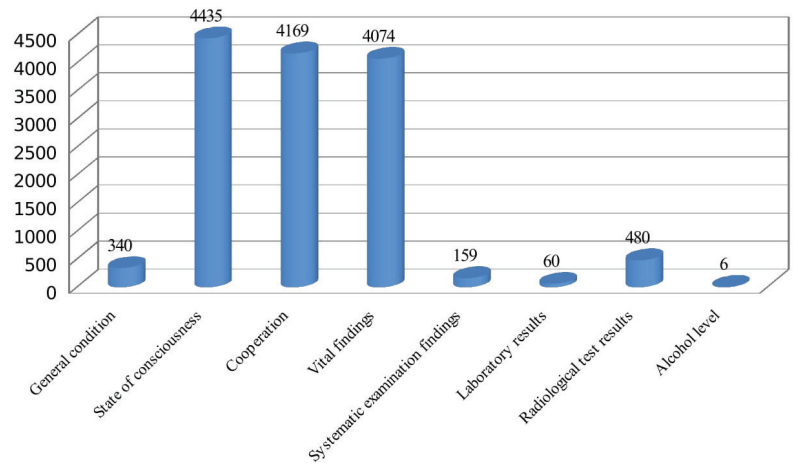

Of medicolegal reports included in the study, $88.3 \%$ contained the date of the incident, $81.3 \%$ covered also the time of the incident, and only $12.9 \%$ included the history of the incident. Medical examination and diagnostic tests conducted during medicolegal evaluation are presented in Graph 3.

Results regarding the description of injuries are presented in Table 2.

Results regarding the report are presented in Graph 4. Referrals were requested for 208 forensic patients, whereas reports belonging to 176 of these patients included the opinions of consulted departments. Nearly all $99.9 \%$ (n: 4,960) were preliminary reports preliminary but $0.0 \%$ (n: 1$)$, whereas $0.1 \%(n: 3)$ of the reports did not specify the report characteristic.

Although the registration number, date and time of issue, reason for referral for undergoing an examination, identification of the person examined, history of the incident, date and time of the examination, localization and size of the lesions, and wound characteristics must be included in medicolegal reports, it was seen that some of these data were missing.

Graph 2

Identification

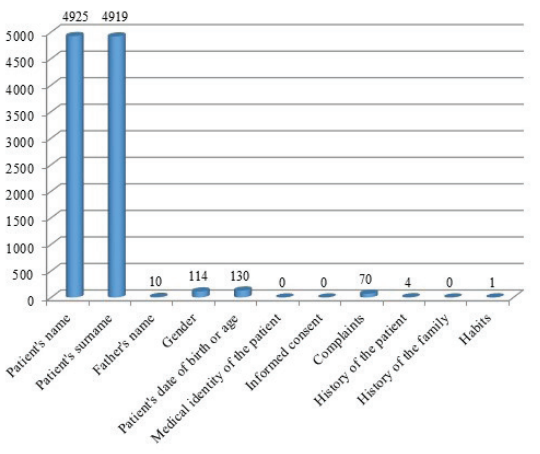

Graph $\overline{4}$

Evaluation concerning the report

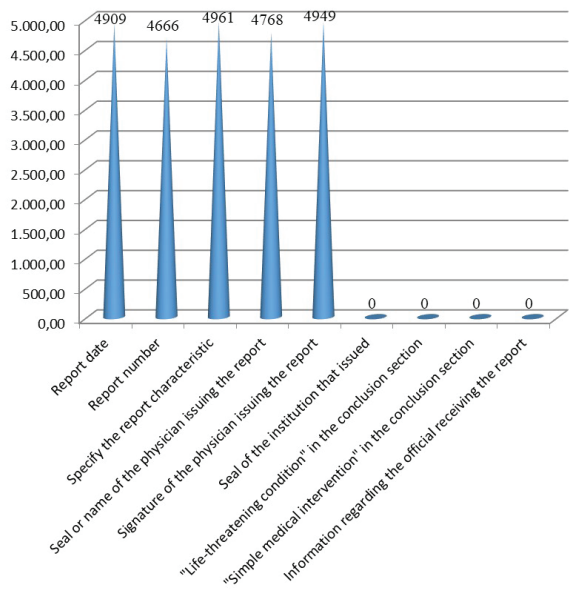




\begin{tabular}{|c|c|c|c|c|c|}
\hline INCIDENT TYPE & AVK (+) & AVK (-) & Total & $\begin{array}{l}\text { AVK (+) } \\
\quad \%\end{array}$ & $\begin{array}{l}\text { TAVK (+) } \\
\%\end{array}$ \\
\hline 1. Blunt Trauma & N(Number) & $N($ Number) & $\begin{array}{c}\mathrm{N} \\
\text { (Number) }\end{array}$ & $\%$ & $\%$ \\
\hline a) Blunt traumatic assault and battery & 1505 & 21 & 1526 & 98.6 & 31.2 \\
\hline b) Pedestrian versus motor vehicle accident & 1146 & 2 & 1148 & 99.8 & 23.8 \\
\hline c) Road traffic accident & 757 & 8 & 765 & 99 & 15.7 \\
\hline d) Fall(s) from height & 366 & 8709 & 9075 & 4 & 7.6 \\
\hline e) Hitting the head against something & 63 & 3 & 66 & 95.5 & 1.3 \\
\hline f) Being hit by a falling object such as a TV or refrigerator & 62 & 0 & 62 & 100 & 1.3 \\
\hline $\begin{array}{l}\text { g) Being hit by a falling object such as a concrete block, } \\
\text { machine, or cabinet }\end{array}$ & 29 & 7 & 36 & 80.6 & 0.6 \\
\hline e) Occupational hazards & 16 & 0 & 16 & 100 & 0.3 \\
\hline \multicolumn{6}{|l|}{ 2. Penetrating Trauma } \\
\hline a) Penetrating stab wound/sharp object injury & 433 & 2 & 435 & 99.5 & 9 \\
\hline b) Gunshot wound & 239 & 2 & 241 & 99.2 & 5 \\
\hline c) Sharp object injury & 17 & 11 & 28 & 60.7 & 0.4 \\
\hline 3. Injury secondary to explosion & 39 & 0 & 39 & 100 & 0.8 \\
\hline \multicolumn{6}{|l|}{ 4. Burns } \\
\hline a) Burns due to electricity & 8 & 5 & 13 & 61.5 & 0.2 \\
\hline b) Burns due to contact with hot water & 8 & 0 & 8 & 100 & 0.2 \\
\hline c) Burns due to flame & 2 & 0 & 2 & 100 & 0.0 \\
\hline \multicolumn{6}{|l|}{ 5. Poisoning } \\
\hline a) Ingesting bleach & 10 & 0 & 10 & 100 & 0.2 \\
\hline b) Ingesting corrosive substances & 2 & 2 & 4 & 50 & 0.0 \\
\hline c) Substance abuse & 2 & 0 & 2 & 100 & 0.0 \\
\hline \multicolumn{6}{|l|}{ 6. Multiple incidents } \\
\hline $\begin{array}{l}\text { a) Blunt traumatic assault and battery + penetrating stab } \\
\text { wound/sharp object injury }\end{array}$ & 74 & 0 & 74 & 100 & 0.2 \\
\hline b) Blunt traumatic assault and battery + gunshot wound & 10 & 0 & 10 & 100 & 0.2 \\
\hline c) Blunt traumatic assault and battery + sharp object injury & 6 & 0 & 6 & 100 & 0.1 \\
\hline d) Fall + sharp object injury & 3 & 0 & 3 & 100 & 0.1 \\
\hline e) Gunshot wound + sharp object injury & 3 & 0 & 3 & 100 & 0.1 \\
\hline f) Blunt traumatic assault and battery + sexual abuse & 1 & 0 & 1 & 100 & 0.0 \\
\hline g) Blunt traumatic assault and battery + sexual violence & 1 & 0 & 1 & 100 & 0.0 \\
\hline \multicolumn{6}{|l|}{ 7. Sexual Violence } \\
\hline a) Anal/genital trauma & 2 & 0 & 2 & 100 & 0.0 \\
\hline b) Sexual abuse & 1 & 0 & 1 & 100 & 0.0 \\
\hline 8. Suicide by jumping from height & 2 & 0 & 2 & 100 & 0.0 \\
\hline 9. Other & 12 & 12 & 24 & 50 & 0.2 \\
\hline Total & 4819 & 8784 & 13603 & 35.4 & 100 \\
\hline
\end{tabular}

AVK (+): Cases with a stamp as forensic cases.

AVK (-): Cases without a stamp as forensic cases, although registered as a forensic case.

AVK (+) \%: Percentage of cases stamped as forensic cases among forensic cases in the row.

TAVK (+) \%: Percentage of cases stamped as forensic cases among forensic cases in the column. 


\begin{tabular}{|l|c|c|c|}
\hline Description of lesion secondary to injury & N (number) & $\mathbf{n}$ (number) & \% (percentage) \\
\hline Lesion size & 3834 & 1869 & 48.7 \\
\hline Lesion color & 1890 & 247 & 13.1 \\
\hline Lesion margin properties & 2441 & 50 & 2 \\
\hline Lesion depth & 2419 & 121 & 5 \\
\hline Lesions checked on the diagram & 3834 & 0 & 0 \\
\hline Comments/results regarding the characteristics of the injury & 3834 & 7 & 0.2 \\
\hline Localization of traumatic lesions & 3834 & 3828 & 99.8 \\
\hline
\end{tabular}

$\mathbf{N}$ : Number of lesions that need to be described $\mathbf{n}$ : Number of described lesions

$\%$ : Percentage of described lesions among those that need to be described $(\mathrm{n} / \mathrm{N})$

\begin{tabular}{|c|c|c|c|c|c|c|}
\hline & $\begin{array}{c}\text { Serinkan } \\
(\mathrm{n}: 3219)\end{array}$ & $\begin{array}{c}\text { Çoltu } \\
\text { (n:2204) }\end{array}$ & $\begin{array}{l}\text { Kahya I } \\
\text { (n:464) }\end{array}$ & $\begin{array}{l}\text { Bozkurt } \\
\text { (n:1218) }\end{array}$ & $\begin{array}{c}\text { Turla } \\
(n: 351)\end{array}$ & $\begin{array}{c}\text { I.T.F } \\
\text { (n:4964) }\end{array}$ \\
\hline Missing identifying information & $\%$ & $\%$ & $\%$ & $\%$ & $\%$ & $\%$ \\
\hline a)Patient's name & 0.3 & 0 & 0.9 & 0.9 & 0 & 0.8 \\
\hline b) Patient's surname & 0.4 & 0 & 0.9 & 0.9 & 0 & 0.9 \\
\hline c) Father's name & 84.9 & 22.41 & & 35.9 & 2 & 99.8 \\
\hline d) Patient's date of birth or age & 87.0 & 6.43 & & 33.8 & 6 & 97.4 \\
\hline \multicolumn{7}{|l|}{ Missing information related to the incident } \\
\hline a)Date of incident & 0.1 & 0.63 & 100 & 37.1 & 9.7 & 11.7 \\
\hline b)Time of incident & 52.1 & 4.85 & 100 & 49.3 & 14.5 & 19.7 \\
\hline c)History of incident & & & 100 & 19.9 & & 87.1 \\
\hline d) Type of incident & 0 & 1.17 & & 4 & & 2.9 \\
\hline \multicolumn{7}{|c|}{ Missing information related to the examination and investigation } \\
\hline a)General condition & 17.4 & & & 35.5 & 61.5 & 93.2 \\
\hline b)State of consciousness & 18.3 & & & 37.3 & 58.7 & 10.7 \\
\hline c)Cooperation & 19.4 & & & & 65.2 & 16.0 \\
\hline d) Systematic examination findings & 25.3 & & 59.9 & & 16.8 & 96.8 \\
\hline e)Laboratory results & & & 69.8 & 96.4 & 0.7 & 98.8 \\
\hline f)Radiological test results & & & 69.8 & 61.7 & & 90.3 \\
\hline g)Alcohol level & 46.9 & 2.54 & & 63 & & 99.9 \\
\hline h) Consultation & & & 53.7 & 84.6 & & 96.5 \\
\hline \multicolumn{7}{|l|}{ Missing information related to the report } \\
\hline a) Report date & & 0.68 & & 56 & & 1.1 \\
\hline b) Report number & & 4.58 & & & & 6 \\
\hline c) Seal or name of the physician issuing the report & 4.2 & 4.17 & 0 & & 8 & 3.9 \\
\hline d) Signature of the physician issuing the report & 0.9 & 2.13 & 0 & & 0.3 & 0.3 \\
\hline e) "Life-threatening condition" in the conclusion section & 0.06 & 2.67 & & & 2.6 & 100 \\
\hline f) Information regarding the official receiving the report & 26.2 & 12.97 & & & 100 & 100 \\
\hline
\end{tabular}




\section{Conclusions}

Besides providing emergency treatment and medical intervention for forensic patients, physicians working at emergency departments are also responsible for issuing medicolegal reports and notifying relevant departments, when necessary (1). The Law Concerning the Mode of Execution for Medicine and Medical Sciences No. 1219 states that "physicians with the right to practice are entitled to issue reports regarding the physical and mental status of individuals." Therefore, all physicians with the right to practice medicine in Turkey are responsible for dealing with forensic cases and issuing medicolegal reports (8).

In the present study, it was assessed that $7.6 \%$ of 5,399 medicolegal reports issued within 3 years were not contained in the archive and that $25(0.5 \%)$ of the available medicolegal reports were illegible. Medicolegal reports are prepared in four copies; one copy is hand-delivered to the person acting on behalf of the institution that requested the report upon signature and under seal, the second copy is delivered to the relevant Public Prosecution Office through official channels in a sealed envelope by the institution that issued the report, the third copy is sent to the Local Health Authority that encompasses the location of the institute that issued the report on a monthly basis to enable making evaluations at the provincial level, and the fourth copy will be stored in the institution that issued the report (6). Illegibility of medicolegal reports leads to significant problems in the preparation of a definitive report and in the judicial process.

According to the results of the study conducted by Canbaz (9), 10,443 patients were admitted to Istanbul Medical Faculty, Trauma and Emergency Surgery Outpatient Clinic at Istanbul University within one year between 01.01.1997 and 12.31.1997 and medicolegal reports were issued for $5,513(52.8 \%)$ patients, whereas our study encompassing three years revealed that 21,500 patients were admitted and that 5,399 (25.1\%) medicolegal reports were issued. Comparing these two studies, it was observed that there has been a decrease in both the number of patients admitted to the same outpatient clinic and the number of patients for whom medicolegal reports were issued. While the decrease in the number of patients can be explained by the increase in the number of centers, the decrease in the number of forensic cases among admissions implies a possible inadequacy in diagnosing and reporting forensic cases.

In the study conducted by Canbaz (9) where 541 forensic cases were reviewed according to the incident type, traffic accidents were leading incidents (56.2\%), while blunt traumatic assault and battery $(13.5 \%)$, and penetrating stab wounds followed (11.8\%). Our study also showed that traffic accidents were the most frequent of incidents (39.5\%) followed by blunt traumatic assault and battery (31.2\%), and penetrating stab wounds (9\%). Considering the distribution of incident types that lead to the issuing of medicolegal reports, our study included traffic accidents in the first place $(39.5 \%)$, which is consistent with the results of similar studies in the literature that indicate traffic accidents are most common (25.9-68.3\%) (10-13). Although there is variability between regions, traffic accidents were in the first place. Similar results obtained in studies conducted in various regions also reveal the extent of traffic accidents in numbers.

Informed consent includes the detailed verbal and written permission granted by a patient after a physician is convinced that the patient is capable of making decisions about his/her treatment and after the physician answers the patient's questions regarding the patient's current health status, diagnosis, incident type, success rate, and duration of treatment modality that needs to be applied and requires interfering with physical integrity, risks of the treatment modality for the patient's health, dosage and possible side effects of the administered medication, consequences of the disease in case the patient refuses the recommended treatment, and possible treatment options and risks in a manner that the patient can comprehend and after the patient reaches the necessary and sufficient level of awareness. Therefore, allied health personnel in emergency departments having the informed consent form signed by patients or their relatives who even do not know the content constitutes a malpractice. The patient or his/her relative signing an informed consent form in this approach is not acceptable both legally and ethically. Obtaining informed consent can be of secondary importance due to the condition of patients in the emergency department, however informed consent must also be obtained from emergency cases (14).

Article 24 of Patient Rights Regulation amended on 05.08.2014 states the following: "Consent of the patient and parents or guardians of the patient, should the patient be minor or placed under guardianship, shall be received for medical interventions. This is not required in case the patient does not have a guardian or parents or if they are not present or in case the patient does not have the capacity to provide consent. Even in cases where the consent of the patient's legal representative would suffice, the participation of the patient in the informed consent process and decisions 
regarding his/her treatment shall be ensured by listening to the minor or disabled patient to clarify that he/ she can understand what is being explained. Health institutions and organizations shall take necessary precautions for informing and obtaining consent of the disabled by considering the nature of their disability. In cases where the legal representative does not consent, if the intervention is medically required, exercising the medical intervention on the patient, who is a minor or placed under guardianship, is subject to court decision as per articles 346 and 487 of the Turkish Civil Code. For a patient who is not able to express his/her requests during medical intervention, his/her previously declared requests regarding medical intervention shall be taken into account. In case of recurrent diseases during which the patient loses competency on occasion, the patient, when he/she is competent, may be requested to provide consent for receiving medical intervention that will be exercised when the patient is not competent. In emergency cases when the patient's consent cannot be obtained and the patient is in a life-threatening condition and unconscious or in cases that will lead to organ loss or to an organ becoming incapable of performing its function, exercising medical intervention on the patient is not subject to receiving consent from the patient. In this case, the required medical intervention is performed and recorded. However, in this case, the patient's relative or legal representative available at the setting shall be informed if possible; otherwise, the patient's relative or legal representative shall be informed after medical intervention. On the other hand, consent procedures for subsequent medical interventions are performed depending on the competency and capacity of the patient after he/she regains consciousness. After inpatient treatment in the health institution and organization is completed, healthcare personnel shall verbally explain to the patient the treatment plan after discharge, including information such as the patient's general health condition, medication, follow-up dates, diet, and what he/she needs to do. Then, a copy of the epicrisis that contains this treatment plan shall be handed over to the patient." (15).

Our study revealed that informed consent was not obtained from any patient; Kahya also reported that informed consent was not obtained from any patient for the reports issued in Emergency Departments of three training and research hospitals in 2005 (16).

Table 3 shows missing data regarding patients' identification in our study and other studies in the references, indicating that the results of our study are consistent with those of studies $(10,11,17)$. According to our study, there were missing information regarding gen- der in $97.7 \%$ of the cases, medical identity in $100 \%$ of the cases, medical complaints in $98.6 \%$ of the cases, medical history in $99.9 \%$ of the cases, and habits in $100 \%$ of the cases; Akıncı (18) et al. reported missing information regarding medical history in $33.3 \%$ of the cases and medical complaints in $10.6 \%$ of the cases, and Ocak (19) et al. reported missing information regarding patient complaints in $26.4 \%$ of the cases . In our study, it was determined that date of admission was missing in $96.6 \%$ of the cases, time of admission was missing in $95.2 \%$ of the cases, and type of admission was missing in 5.5\% of the cases; Kahya reported that $100 \%$ of the reports included the date and time of the examination (16).

Missing information regarding the incident type in other studies and in our study is shown in Table 3. Güven (20) et al. reported that the date of the incident was not specified in $4.4 \%$ of the cases and that the type of incident was not specified in $7.6 \%$ of the cases, which are both in agreement with the results obtained in our study.

Missing information related to examination findings in other studies in the literature and in our study is provided in Table $3(10,11,16,17,21)$. Bozkurt (11) et al. reported that information regarding vital signs was missing in $67 \%$ of the cases, whereas the same rate was found to be $17.9 \%$ in our study. It was also determined that opinions of the consultants were not recorded in 32 medicolegal reports. Consultation is the deliberation between the attending physician who is primarily responsible for the patient and another physician from another field of specialty who has the knowledge and experience regarding the disease/treatment/medical intervention and related issues. The consulting physician should be an expert in his/her own specialty, or the consultation should be carried out under the supervision of a specialist. The attending physician might request a consultation with the consulting physician verbally or in writing. In emergency cases, a request is made verbally, but the written request form should be filled. The consulting physician and primary physician are equally important for the patient; therefore, the consulting physician has an important role in malpractice suits.

Missing information related to the description of lesions secondary to injury in our study and in other studies is presented in Table 3 . In the study conducted by Bozkurt (11) et al. and Kahya (16), the rates of missing data regarding the description of lesions secondary to injury were reported as $13.9 \%$ and $41.2 \%$, respectively; missing data related to the description of lesions secondary to injury was elaborated in our 
study, and it was seen that data regarding lesion size was missing in $51.3 \%$ of the cases, lesion color was missing in $86.9 \%$ of the cases, lesion margins were missing in $98 \%$ of the cases, and lesion depth was missing in $95 \%$ of the cases. In the study conducted by Ocak (19) et al., it was seen that data regarding examination findings was missing in $0.8 \%$ of the cases, wound localization was missing in $6.4 \%$ of the cases, wound size was missing in $24.8 \%$ of the cases, wound characteristics were missing in $19.9 \%$ of the cases, and ecchymosis/hematoma color was missing in $98.2 \%$ of the cases. In studies, the rate of missing data regarding the indication of lesions on the diagram was reported to be between $5.1 \%$ and $32.7 \%$, whereas this rate was $100 \%$ in our study, a finding inconsistent with other studies $(11,17)$. In our study, the localization of traumatic lesions was not specified in $0.2 \%$ of the cases, whereas in the study conducted by Güven, this rate was reported as $6.2 \%(20)$.

The review of medicolegal reports in our study revealed that properties of external traumatic lesions such as size, color, margin properties, and depth were not specified in most reports. Article 276 of the Turkish Criminal Code no. 5237 states the following regarding a wrong decision made by the expert, i.e., the physician, issuing the medicolegal report: "In case of declaration of opinion contrary to the truth by the expert, punishment with imprisonment from one year to three years is applicable." There are many examples of this with ongoing or pending investigations in local courts and the Disciplinary Committees of Chambers of Medicine $(17,22)$.

Conducting a complete, accurate, and proper examination; indicating the findings of an examination in an understandable manner; and preparing a medicolegal report in accordance with the legal standards in the course of identifying and reporting forensic cases lead to a rapidly and accurately executed judiciary system (16).

According to the Turkish law, judicial authorities postulate the evaluation of injuries in terms of life-threatening conditions and simple medical intervention in the preparation of medicolegal reports. It is stated that ignoring this evaluation leads to insufficient information in the reports as well as to obstruction of justice (23). In our study, it was determined that none of the medicolegal reports included information regarding life-threatening condition or simple medical intervention, whereas in the study conducted by Zeren et al., it was reported that simple intervention was not performed in $13.9 \%$ of the patients and life-threatening conditions were not evaluated in $0.4 \%$ of the patients presenting to the emergency department (23). Keten et al. reported that there was no information regarding whether the condition could be alleviated by simple medical intervention in $87 \%$ of the cases (12). Ocak (19) et al. reported that the criterion of life-threatening condition was not specified in $37.9 \%$ of the cases, whereas Güven (20) et al. reported that the life-threatening condition was not written in $19.7 \%$ of the cases. Serinkan (10) et al. determined that information on the life-threatening condition was missing in $0.06 \%$ of the cases. Therefore, our study was not in line with the studies in the literature.

Medicolegal reports are classified as injury reports, sex crime reports, alcohol reports, reports of criminal liability for the child, reports of capacity to act, criminal liability reports, age determination reports, and other medicolegal reports in terms of their intended use. In terms of results, these reports are divided into three groups: preliminary-preliminary reports, definitive reports, and supplement reports (24).

The vast number of preliminary-preliminary reports and possible errors and missing data in these preliminary-reports lead to prolonged procedural acts, situations that are difficult to resolve, prolonged prosecution processes, and an increase in the number of applications to hospitals and forensic units for the preparation of definitive reports and therefore to increased work load in relevant units (25).

Eroğlu (26) et al. reported in their study conducted in the Emergency Department of a public hospital that $77.8 \%$ of physicians felt confident and that $36.4 \%$ of physicians habitually added "preliminary-preliminary report" to the conclusion section of their report.

Missing information in the reports according to our study and other studies is presented in Table 3 . Keten (12) et al. reported that considering the type of issued reports, $79 \%$ of reports were preliminary-preliminary and $9 \%$ were definitive. Serinkan (10) et al. stated that nearly $20 \%$ of medicolegal reports were definitive and $79.87 \%$ thereof were preliminary, whereas Bozkurt (11) et al. stated that $0.7 \%$ of medicolegal reports were definitive and $93.4 \%$ were preliminary-preliminary, in addition to reports not indicated as either preliminary-preliminary or definitive (rate of 5.8\%). In the study conducted by Kahya, definitive reports were not issued for any forensic case and preliminary-preliminary reports were issued for $95.5 \%$ of forensic cases (16). Akıncı (18) et al. stated that $65.7 \%$ of case reports were preliminary and $9.3 \%$ of case reports were definitive, whereas report characteristics were not specified in $24.9 \%$ of reports. Korkmaz (13) et al. re- 
ported that preliminary reports were issued for $69.8 \%$ of forensic cases and definitive reports for $14.4 \%$ of forensic cases. In our study, $0.0 \%$ ( $n$ : 1) of medicolegal reports were definitive and 99.9\% (n: 4,960) were preliminary, whereas $0.1 \%(n: 3)$ of reports had no specification of preliminary or definitive. According to a survey conducted by Tümer (27) et al. on surgeons, it was suggested that physicians refrain from issuing definitive reports and that most medicolegal reports are issued as preliminary reports. Demirci et al. conducted a study on physicians working at the Emergency Department and evaluated reports before and after a hands-on training program was conducted on medicolegal report writing for 3 days. According to this study, physicians added "preliminary report" to the conclusion section of $55.5 \%$ of the reports prepared before training, whereas they added the same to the conclusion section in only $0.5 \%$ of the reports after training. This on-the-job training has created an impact in terms of eliminating drawbacks (28).

Alcohol testing, which has a great importance in forensic cases and primarily in car accidents, should be used in conjunction with physical examination findings as well as biochemical analyses. The incapability of a notable trauma center to conduct blood alcohol analysis is a significant drawback. As seen in some studies involving emergency departments, laboratories that perform biochemical analyses do not perform alcohol analysis; it is important to note this as an important necessity that needs to be satisfied in trauma centers as soon as possible (12).

Studies in the literature have reported that blood samples were collected from $40 \%$ of patients determined to be the driver in car accidents (29); in a similar study, it was specified that no blood samples were collected from the patients for blood alcohol analysis. According to our study, laboratory evaluations related to blood alcohol level were not performed in Istanbul Medical Faculty Hospital, but blood alcohol levels were present in six reports as these patients were referred from another hospital.

Korkmaz (13) et al. reported that $20 \%$ of forensic patients did not have any signs of injury on their body, whereas this rate was found to be $22.8 \%$ in our study. Considering missing information related to the description of lesions secondary to injury reported by this study and the fact that almost all reports are issued as preliminary reports, a definitive report that will be prepared a long time after the incident will be incomplete and contain errors as lesions not specified in the preliminary report will have healed by then; this situation will lead to loss of rights for the individual.
Çoltu (21) et al. and Türkmen (1) et al. reported the rate of cases marked as forensic cases in emergency registration books as $43.6 \%$ and $76 \%$ between 1995 and 1997 and between 04.01.2002 and 03.31.2003, respectively, whereas in our study, this rate was found to be $35.4 \%$. Lower rates reported in our study in comparison to those in the reports in the references reveal that physicians working at trauma and emergency surgery outpatient clinics do not know the concept of forensic cases.

According to the results of our study, the rate of marking falls/fall from height as forensic case in the registration book of the Trauma and Emergency Surgery Outpatient Clinic was 4\%. These cases have to be carefully differentiated from cases that cannot be evaluated as forensic cases such as minor home accidents. In the studies conducted by Çoltu et al. and Türkmen et al., $17.05 \%$ and $55 \%$ of cases of falls/fall from height were marked as forensic cases, respectively $(21,1)$

In emergency units, factors such as patient overload, lack of knowledge in issuing medicolegal reports, and lack of in-service training after graduation lead to incomplete or erroneous medicolegal reports by physicians. Yavuz (30) et al. stated that although physicians take forensic medicine courses during their life as a student, 95\% of them do not have sufficient knowledge and/or skills regarding forensic medicine and its applications.

In conclusion, while providing the necessary care to forensic patients, physicians working at emergency trauma departments are obliged to identify whether it is a forensic case, and after identifying it as a forensic case, examine, collect and keep all materials qualifying as medical evidence, perform a thorough examination under proper and suitable conditions, and inform judicial authorities (16 ).

After the Code of Criminal Procedure no. 5271 and the Turkish Criminal Code no. 5237 took effect on 06.01.2005, circular no. 13292 regulating the Principles of Conduct in Forensic Medicine Services was published by the Ministry of Health General Directorate of Basic Health Services on 09.22.2005. Upon the publication of this circular, guidelines for the evaluation of criminal injuries defined in the Turkish Criminal Code with regard to forensic medicine and the preparation of medicolegal reports were prepared by the Ministry of Justice, Directorate of Forensic Medicine Institute, Forensic Medicine Specialists Association, and Forensic Medicine Association in 2005 and were updated in 2013. Although report number, date 
and time of issuing the report, reason for referral to undergo examination, identifying information of the patient examined, history of the incident, date and time of performing the examination, localization and size of the lesions, and characteristics of the wound must be mandatorily included in medicolegal reports, it was determined that some of these data were missing and erroneous $(6,7)$.

Physicians will be legally liable for any mistake in and missing data in medicolegal reports, similar to malpractice cases, and they can be faced with criminal action and sued for damages (10).

As reported in various studies, on-the-job training programs make it possible to reduce missing data or errors (26).

In conclusion, physicians should conduct detailed evaluations as per articles related to forensic cases in the Turkish Criminal Code and issue medicolegal reports using standard practices. It was considered that the number of errors in medicolegal reports issued in trauma and emergency surgery outpatient clinics of our university can be reduced and that medicolegal reports can be prepared more in line with the standards of "Forensic case, Medicolegal Report Preparation"; amendments made in fundamental laws and regulations should be included in physicians' on-thejob training programs, and these training programs should be periodically provided. University hospitals are also auspiciously equipped with departments of forensic medicine whereas forensic cases might be referred to, and forensic physicians can get involved with an adequate evaluation process to decide whether cases have medicolegal aspects. Henceforth a team work with multidisciplinary approach might prevent evidence to be lost through work load.

Bu çalışma 11-15 Nisan 2018 tarihleri arasında Antalya'da düzenlenen 21. Ulusal Cerrahi kongresinde sözel sunum olarak sunulmuştur.

\section{References}

1. Türkmen N, Akgöz S, Çoltu A, Ergin N. Uludağ Üniversitesi Tıp Fakültesi Acil Servisine Başvuran Adli Olguların Değerlendirilmesi. Uludağ Üniversitesi Tıp Fakültesi Dergisi 2005;31 (1)259.

2. Tüzün B, Elmas i, Akkay E. Adli rapor düzenlenme zorunluluğuna hekimlerin yaklaşımı: Anket çalışması. Adli Tıp Bülteni 1998; 3(1)27-31.

3. Arıkan H. T.C. Anayasası- Türk Ceza Kanunu- Ceza Mahkemesi Kanunu: İstanbul 2005 1. Baskı. 322.

4. Özaslan A, Kolusayın Ö. Hekimin Yasal Sorumlulukları. Adli Tıp Ders Kitabı. Cerrahpaşa Tıp Fakültesi Yayınları, İstanbul 2011; s:13-40.

5. Adli Tıp Uzmanları Derneği. Birinci Basamak İçin Adli Tıp El
Kitabı. Ankara. Polat Matbaası. 1999: 14-6. 90.s:114-5.

6. Adli tabiplik hizmetlerinin yürütülmesinde uyulacak esaslar. Sağlık Bakanlığı-Temel Sağlık Hizmetleri Genel Müdürlüğü. Genel Tarihi: 22.09.2005, Sayı: B.10.0.TSH.013.003-13292. http://www.ttb.org.tr/mevzuat/index.php?option=com_content\&task=view\&id=95\&itemid=35.) (Erișim tarihi: 06.05.2017).

7. Gündoğmuş ÜN, Balcı Y, Akın M. TC Adalet Bakanlığı, Adli Tıp Kurumu Türk Ceza Kanunu'nda tanımlanan yaralama suçlarının adli tıp açısından değerlendirilmesi. Haziran-2013

8. 1219 sayılı Tababet ve Şuabatı Sanatlarının Tarzı İcrasına Dair Kanun http://www. mevzuat. Adalet.gov.tr/htlm/451.htlm.

9. Canbaz K. Illk ve Acil Yardım Tedavi Basamağında Adli olguIarın Değerlendirilmesi. İstanbul Üniversitesi İstanbul Tıp Fakültesi Adli Tıp Anabilim Dalı Uzmanlı Tezi, İstanbul: İstanbul Üniversitesi.1998.

10. Serinkan M, Türkçüer I, Acar K, Özen M. Acil Servis hekimleri tarafından düzenlenen adli raporların eksiklikler ve yanlışlıklar yönünde değerlendirilmesi. Ulus Travma Acil Cerrahi Derg. 2011;17 (1):23-8.

11. Bozkurt S, Daraoğlu V, Okumuş M, Savrun A, Karanfil R, Gök AA. Acil Serviste Düzenlenen Adli Raporların Uygunluğunun Değerlendirilmesi ve Tespit Edilen Eksiklikler. J Clin Anal Med 2015;(3):331-4.

12. Keten A, İçme F, Eser M, Kılınç I, Tümer AR. Acil Serviste Düzenlenen Adli Raporların TCK Kapsamında Değerlendirilmesi, Turkish Medical Journal 2011; (5)3: 94-9.

13. Korkmaz T, Kahramansoy N, Erkol Z, Sarıçil F, Kılıç A. Acil Servise Başvuran Adli Olguların ve Düzenlenen Adli Olguların Değerlendirilmesi. Haseki Tıp Bülteni 2012; 50;1:14-20.

14. i..Ü. Cerrahpaşa Tıp Fakültesi Sürekli Tıp Eğitim Etkinlikleri Sempozyum Dizisi No: 78, 2012 Ed: Prof. Dr. Gürsel ÇETiN, Uzm. Dr. Ahsen KAYA 2012, bölümü yazan Prof. Dr. Gürsel ÇETIN, s: 22-31.

15. Sağlık Bakanlığı Hasta Hakları Yönetmeliği Resmi Gazete tarihi: 01.08.1998 Resmi Gazete sayısı: 23420, Madde 24 (Değişik tarihi: 08.05.2014, Resmi Gazete sayısı: 28994).

16. Kahya i. İstanbul ili üç büyük devlet hastanesi Acil servislerinde muayeneleri yapılan ve Adli raporları düzenlenen olgularda adli tıbbi yaklaşım ve kayıt sisteminin irdelenmesi. İstanbul Üniversitesi Adli Tıp Enstitisü Sosyal Bilimler Anabilim Dalı Yüksek Lisans Tezi. İstanbul: İstanbul Üniversitesi. 2005.

17. Turla A, Aydın B, Sataloğlu N. Acil Serviste düzenlenen adli raporlardaki hata ve eksiklikler Ulus Travma Acil Cerrahi Dergisi 2009;15(2):180-4.

18. Akıncı GE, Şahin E, Şimşek I, Çakmakçı G, Şener AE. Başkent Üniversitesi Ankara Hastanesi Acil Servisi'nde 2013 yılında düzenlenen adli bildirim raporlarının Değerlendirilmesi. 14-16 Mayıs 2014. XVI. Öğrenci Sempozyumu Çalışma Grubu Sunumları (Sözel sunum 20)

19. Ocak S, İnanıcı M.A. Marmara Üniversitesi Hastanesi Acil Servisi'nde düzenlenen Adli raporların değerlendirilmesi. Yıllık Adli Tıp Toplantıları-2002 kitabı Antalya 16-19 Mayıs 2002; s:152-6.

20. Mutlu Kukul Güven F, Bütün $C$, Yücel Beyaztaş $F$, Eren ŞH, Korkmaz i. Cumhuriyet Üniversitesi Tıp Fakültesi Hastanesine Başvuran Adli Olguların Değerlendirilmesi. ADÜ Tıp Fakültesi Dergisi 2009;10(3):23-8.

21. Çoltu MA, Durak D, Fedakar R. Uludağ Üniversitesi Tıp Fakültesi Acil Servisi'nde Düzenlenen Adli Rapor Formlarının Değerlendirilmesi, Adli Tıp Bülteni, 5 (1): 36 - 40.

22. Türk Ceza Kanunu Madde 276 Resmi Gazetede kabul tarihi 26.09.2004.

23. Zeren C, Karakuş A, Çelikel A, Çalışkan K, Aydoğan A, Karanfil $R$ et al. Mustafa Kemal Üniversitesi Tıp Fakültesi Acil Servisine Başvuran Adli Olguların Değerlendirilmesi. Mustafa Kemal Üniversitesi Tıp Fakültesi Dergisi 2011; cilt 2 sayı 7.

24. Özaslan A. Rapor Türleri ve Hazırlama Teknikleri. Adli Tıp Ders Kitabı (içinde), İstanbul Üniversitesi Cerrahpaşa Tıp Fakültesi Yayınları Rektörlük No:4898, İstanbul Üniversitesi Basım ve Yayınevi Müdürlüğü, İstanbul, 2011; s.595-611. 
25. Çolak B, Demirbaş i, Albayrak Ü, Geçici Adli Raporların Önemi: Olgu Sunumu. STED Dergisi 2005;14: 161-4.

26. Eroğlu SE, Toprak SN, Karataş AD, Onur Ö, Özpolat Ç, Salçın E et al. Acil Hekimi için "Geçici" Adli Raporların Anlamı Nedir? Kendini Koruma ? Önyargı ? Alışkanlık ? Tr J Emerg Med 2013;13 (1):13-8.

27. Tümer AR, Hancı IH. Adli Raporlar ve Cerrahi Hekimleri. Ulusal Cerrahi Derg. 2002; 18(2) :112-7.Demirci \$, Günaydın G, Doğan $\mathrm{H}$, Aynacı $\mathrm{Y}$, Deniz İ. Adli rapor düzenlemede uygulamalı eğitimin önemi. Adli Tıp Dergisi 2007;21 (1):10-4

28. Demirci Ş, Günaydın G, Doğan H, Aynacı Y, Deniz i. Adli rapor düzenlemede uygulamalı eğitimin önemi. Adli Tıp Dergisi 2007;21 (1):10-4.

29. Bilgin UE, Meral O, Koçak A, Aktaş EÖ, Kıyan S, Altuncı YA. 2011 yılında trafik kazası sonucu Ege Üniversitesi Hastanesi Acil Servisine başvuran hastaların adli tıbbi boyutuyla incelenmesi. Ege Journal of Medicine 2013;52(2):93-9.

30. Yavuz Y, Yürümez $Y$, Küçüker $H$, Demirel R, ikizceli İ, Akdur O. Acil Tıp Hekimlerinin Adli Rapor Düzenlenmesi ile illgili Bilgi, Tutum ve Davranışlarının Değerlendirilmesi. Tr J Emerg Med 2004; 4(2), 64 - 7 . 